\section{Dilemas na gestão das águas de nascentes no Cariri, Ceará, Brasil (2014 - 2016)}

\section{Issues Concerning Water Source Management in Cariri, Ceará, Brazil (2014-2016)}

\section{Daniele Costa da Silva}

Universidade Estadual Vale do Acaraú - UVA

Ceará, Brasil

daniele_costa@uvanet.br

(iD) 0000-0002-6128-3273

\section{Información del artículo:}

Recibido: 5 abril 2019

Revisado: 18 agosto 2020

Aceptado: 19 diciembre 2020

$\begin{array}{ll}\text { ISSN } & 2340-8472 \\ \text { ISSNe } & 2340-7743 \\ \text { DOI } & 10.17561 / \text { AT. } 18.4713\end{array}$

(c) $\mathrm{CC}-\mathrm{BY}$

(C) Universidad de Jaén (España). Seminario Permanente Agua, Territorio y Medio Ambiente (CSIC)

\section{RESUM 0}

O texto analisa os dilemas associados à gestão das águas de nascentes na região do Cariri, historicamente marcada por uma experiência de mercado de águas, e os atuais desafios da gestão das águas perpetrados pelo Estado. O Cariri, situado no estado do Ceará, semiárido brasileiro, configura caso emblemático para se pensar as tensões entre disponibilidade hídrica, escassez e partilha da água. o trabalho resulta de observações feitas em reuniões promovidas pela Companhia de Gestão de Recursos Hídricos do Ceará - COGERH para "mediação de conflitos" e da leitura de atas, relatórios e documentos técnicos produzidos sobre esses processos de "mediação", entre 2014 e 2016. Observamse diversas significações associadas aos distintos usos da água e dilemas relativos ao seu acesso, apesar da definição legal estabelecer seu domínio público.

PALAVRAS-CHAVE: Gestão de água, Semiárido, Conflitos socioambientais

\section{ABSTRACT}

This study analyses the issues related to water source management in Cariri, which is historically marked by water market experiences, and the current challenges concerning water management in the state. Cariri is located in the state of Ceará, a semi-arid Brazilian state, and is an emblematic case when considering the tension between water availability, water scarcity, and water sharing. The study is based on observations made in a series of meetings promoted by the Water Resources Management Company of Ceará, COGERH, regarding "conflict mediation" as well as on the minutes, reports, and technical documents produced during these "mediation" processes between 2014 and 2016. The essay reveals the existence of multiple meanings associated with the different uses of water and the dilemmas related to its access, despite the legal definition establishing its public domain.

KEYWORDS: Water management, Semi-arid, Socio-environmental conflicts 
Dilemas en la gestión del agua de manantial en Cariri, Ceará, Brasil (2014-2016)

\section{RESUMEN}

El texto analiza los dilemas asociados a la gestión del agua de manantial en la región de Cariri, históricamente marcada por una experiencia en el mercado del agua, y los desafíos actuales de gestión del agua perpetrados por el Estado. Cariri, ubicado en el estado Ceará, zona semiárida de Brasil, es un caso emblemático para abordar las tensiones entre la disponibilidad de agua, la escasez y el intercambio del agua. El trabajo resulta de las observaciones realizadas en las reuniones promovidas por la Compañía de Gestión de Recursos Hídricos de Ceará-COGERH para la mediación de conflictos y la lectura de actas, informes y documentos técnicos producidos en estos procesos de mediación, entre 2014 y 2016. Se observan varios significados asociados con los diferentes usos del agua y los dilemas relacionados con su accesibilidad a pesar de la definición legal que establece su dominio público.

PALABRAS CLAVE: Gestión del agua, Semiárido, conflictos

socioambientales

Dilemmes dans la gestion de l'eau de source à Cariri, Ceará, Brésil (2014 - 2016)

\section{RÉSUMÉ}

Dans ce texte on analyse les dilemmes liés à la gestion de l'eau de source dans la région de Cariri, région historiquement marquée par le marché de l'eau et les défis contemporains de la gestion publique de l'eau. Région semiaride du Brésil, Cariri se trouve dans l'état de Ceará et elle représente un cas emblématique pour aborder les tensions existantes entre la disponibilité, le manque et l'échange d'eau. Ce travail est le résultat des observations réalisées lors des réunions organisées par la Compagnie de Gestion de Ressources en Eau de Ceará - COGERH, pour améliorer la médiation des conflits et la lecture des actes, rapports ainsi que des documents techniques issus de ces médiations entre 2014 et 2016. On observe plusieurs significations liées aux différentes utilisations de l'eau et les dilemmes associés à l'accès de l'eau malgré la définition légale qui établit son domaine public.

MOTS-CLÉS: Gestion de l'eau, Semi-aride, Conflits socio-

environnementaux
Dilemma nella gestione dell'acqua della sorgente in Cariri, Ceará, Brasile (2014-2016)

\section{SOMMARIO}

Il testo analizza i dilemmi associati alla gestione dell'acqua di sorgente nella regione di Cariri, storicamente segnata da un'esperienza nel mercato dell'acqua, e la sfida attuale della gestione perpetrata dallo Stato. Cariri,situata nello stato Ceará, zona semi-arida di Brasile, è un caso emblematico che approccia le tensioni tra la disponibilità dell'acqua, la carenza e lo scambio dell'acqua.Il lavoro risulta dalle osservazioni effettuate nelle riunioni promosse dalla Compagnia di Gestione di Risorse Idriche di Ceará - COGERH per la mediazione di conflitti e la lettura di certificazioni, rapporto e documenti tecnici fatti in questi processi di mediazione, tra il 2014 e il 2016. Si osserva vari associati con i diversi usi dell'acqua e i dilemmi relazionati con la sua accessibilità nonostante la sua definizione legale che stabilisce il suo dominio pubblico.

PAROLE CHIAVI: Gestione dell'acqua, Semi-arido, Conflitti socioambientali 


\section{Introdução}

Complexas são as dimensões associadas à água, seus usos, formas de apropriação, representações simbólicas e conflitos atinentes. Mais que recurso natural finito, ou insumo indispensável às atividades produtivas, a água é elemento vital e insubstituível a todas as formas de vida. Envolve representações, valores, éticas, interesses múltiplos e assimétricos em disputa ${ }^{1}$. Poder-se-ia pensar a temática da água como um fato social total ${ }^{2}$, pelas imbricações sociais, políticas, culturais, econômicas e físico-naturais implicadas nos seus usos e percepções. Diz-se que a água estará na origem de conflitos bélicos no futuro ${ }^{3}$. De acordo com relatório da Unesco ${ }^{4}$, lançado em março de 2019, os conflitos associados à água triplicaram desde 2010, saindo de 94 registros entre 2000 e 2009, para 263, entre 2010 e 2018. Os dados precisam ser lidos com cautela, como atesta o relatório, mas denotam uma tendência mundial.

Apesar dos crescentes conflitos internacionais, são os intranacionais exatamente aqueles que ocorrem com mais frequência ${ }^{5}$ e os que nos interessam em especial. No Brasil, o levantamento da Comissão Pastoral da Terra, sobre os conflitos pela água no campo ${ }^{6}$, aponta para um número progressivo de conflitos relacionados à água, passando de 45, em 2009, para 276, em 2018.

$\mathrm{Na}$ verdade, os conflitos socioambientais, sobretudo os referentes à água, são de múltiplas causas e escalas. Podem advir de distintos fatores: distribuição desigual das fontes de água, serviços de abastecimento precários, formas históricas de uso e apropriação ou mesmo de diferentes percepções e valores sobre as águas.

A água se apresenta como tema complexo e multidisciplinar. Em vista disso, demanda uma aproximação mais efetiva dos estudos sociológicos, mormente sobre a discussão da água como direito humano, bem público e fonte de conflitos. A Sociologia pode tornar mais claros os processos sociais existentes na base dos conflitos socioambientais ${ }^{7}$. Conforme destaca Acserald ${ }^{8}$, esses conflitos devem ser pensados sob o prisma das

\footnotetext{
1. Galizoni, 2013. Jacobi e Sinisgalli, 2009.

2. Mauss, 2003.

3. Bouguerra, 2004.

4. Unesco, 2019.

5. Castro, 2016.

6. Comissão Pastoral da Terra, 2019.

7. Castro, 2016.

8. Acselrad, 2004.
}

diferentes e contraditórias formas de apropriação material e simbólica dos recursos naturais entre os grupos, classes e segmentos sociais nos territórios. Dentre essas contradições a água pode emergir como bem público ou bem econômico'.

Eis a perspectiva do presente artigo. Nele buscamos pensar os dilemas relacionados aos usos locais da água de nascentes (ou fontes), situadas na Chapada do Araripe, ao sul do estado do Ceará, Nordeste do Brasil, na região conhecida como Cariri (Mapa 1).

Nosso objetivo concentra-se em compreender as disputas em torno dos múltiplos usos da água e como atua o estado para efetivar processos de gestão num contexto semiárido. O Cariri é tomado como caso emblemático para pensarmos as relações entre conflitos socioambientais e escassez e disponibilidade hídricas, por se constituir como território associado à abundância de água. Ao contrário da imagem de escassez prevalecente no Ceará, o Cariri se apresenta como uma área diferenciada do semiárido.

O trabalho baseia-se na observação de reuniões de "mediação de conflitos" entre "usuários de água", realizadas pela Companhia de Gestão dos Recursos Hídricos do Estado do Ceará - COGERH ${ }^{10}$, onde atuamos como técnica do Núcleo de Gestão da Gerência Regional da Sub-bacia do Rio Salgado, entre 2014 e 2016. Nos fundamentamos, de outro modo, na leitura de atas, relatórios e documentos técnicos produzidos pela COGERH nesse período. Apesar do recorte temporal recente, nosso estudo recobre épocas mais remotas, na tentativa de melhor compreendermos as implicações atuais de antigos usos das águas.

Antes, porém, cabe uma discussão sobre o processo de gestão da água no Ceará, estado encravado no semiárido brasileiro.

\section{Água, Semiárido e política no Ceará}

"A água não é um produto como os outros"11. É elemento vital, limitado, insubstituível. Como, então, têm se estabelecido os processos definidores das formas de uso, acesso e distribuição da água, em particular nas regiões semiáridas, onde o tema adquire contornos mais complexos?

\footnotetext{
9. Panez-Pinto, Faúndez-Vergara y Mansilla-Quiñones, 2017.

10. Criada em 1993, a COGERH é a instituição do estado do Ceará responsável pela gestão das águas.

11. Bouguerra, 2004, 131.
} 
Mapa 1. Localização da Região do Cariri, Ceará, Brasil

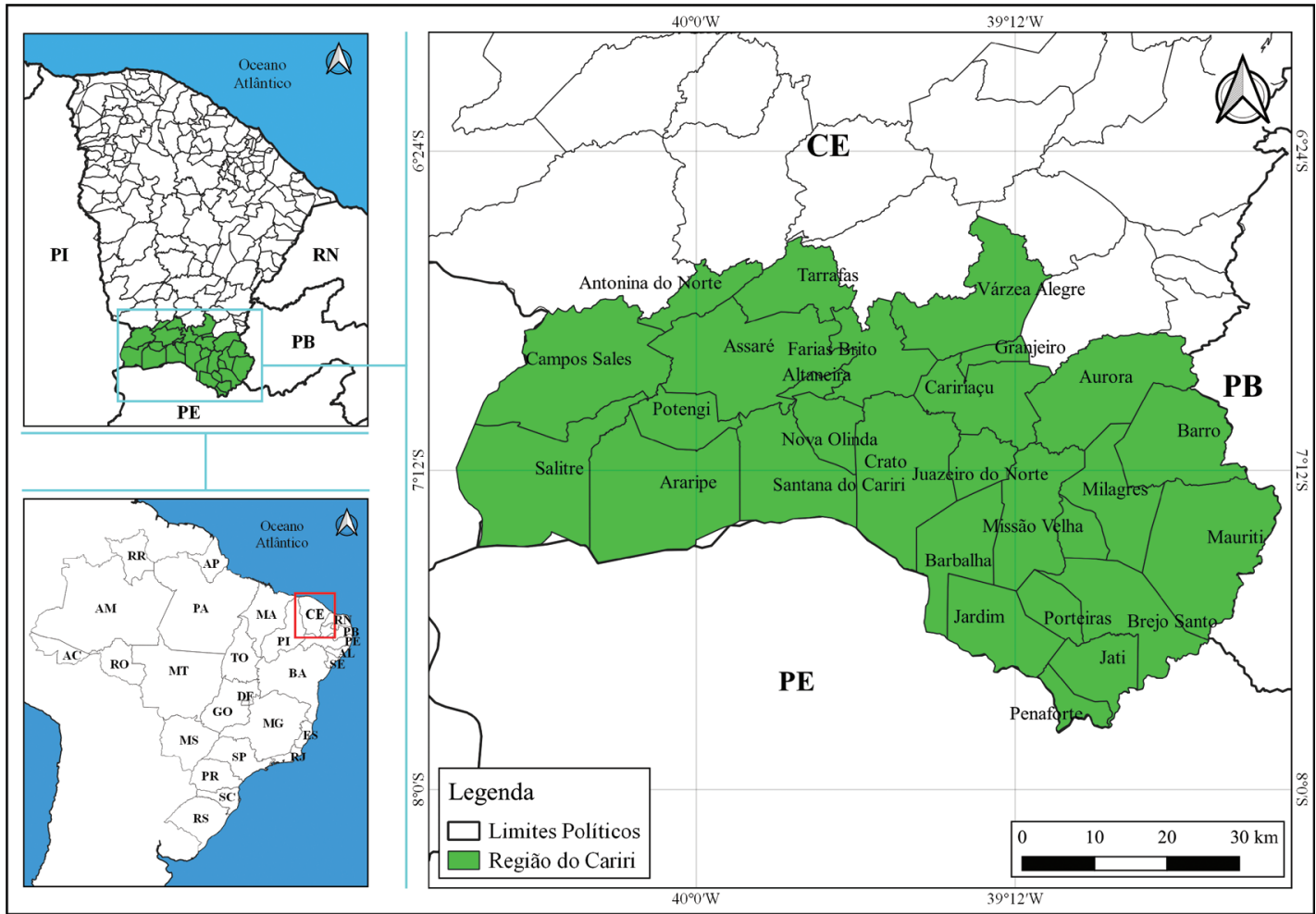

Fonte: Elaboração própria, 2020.

O estado do Ceará é marcado pela condição de semiaridez. Mais de 70\% de seu território está inserido no semiárido brasileiro, onde as precipitações pluviométricas são irregulares, no tempo e no espaço, os solos são rasos e pedregosos, os rios naturalmente intermitentes e parte considerável da água se perde por evaporação. A forma encontrada para lidar com a incerteza permanente sobre a disponibilidade de água tem sido, ao longo da história, a estocagem.

As estiagens, componentes desse cenário, têm gerado iniciativas seculares de governos e organismos da sociedade civil, no sentido de construir alternativas para a convivência com a irregularidade climática. Essa perspectiva deu origem a uma série de ações, políticas públicas, arranjos institucionais e obras de engenharia, na tentativa de reduzir ou eliminar os "efeitos da seca". Porém, a escassez não se explica, exclusivamente, como resultado de processos naturais e climáticos, mas é sobretudo o resultado de interações entre fatores naturais e sociais, quando os últimos exercem papel dominante ${ }^{12}$. A água não falta o tempo todo, nem falta para todos da mesma forma. É preciso considerar as maneiras como a água é, ou não, partilhada, como se estabelecem os acordos ou disputas em torno do seu acesso e como atua o estado diante de tais confrontos. Em especial, importa discutir ideias de escassez e abun-

\footnotetext{
12. Castro, 2016, 35
}

dância, no sentido de desnaturalizar processos definidores de usos e acessibilidades. Como assinala Orellana-Gavidia ${ }^{13}$, "la construcción social de la escassez es relativa y no tiene necessariamente uma base ecológica real".

Os rios do semiárido cearense já não são todos intermitentes, como outrora. Hoje os principais rios estão perenizados por grandes reservatórios ${ }^{14}$, construídos em diversas bacias hidrográficas. Esses mananciais, além de originarem uma "geografia artificial das

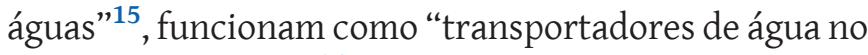
tempo e no espaço" ${ }^{\text {16 }}$. Acumulam água no primeiro semestre do ano, para ser usada nos períodos mais secos, liberando-a no leito dos rios ou em canais construídos para as transferências hídricas.

Os reservatórios são as primeiras e têm sido as principais intervenções públicas no semiárido. Tal iniciativa ficou conhecida, a princípio, como "solução hidráulica". Neste caso, houve uma ampliação da capacidade de reservação hídrica, sem apresentar, como contraponto, mudanças na estrutura de poder existente. As infraestruturas atenderam, principalmente, aos usos privados existentes nas bacias. Além dessas, outras propostas de "solução técnica" foram desen-

\footnotetext{
13. Orellana-Gavidia, 2013, 30.

14. No Nordeste brasileiro, os reservatórios são popularmente denominados "açudes".

15. Brito, 2016

16. Souza Filho, 2011.
} 
volvidas. Porém, pautaram-se pela padronização e massificação no território, sem levar em conta a heterogeneidade social e natural características do semiárido ${ }^{17}$.

As infraestruturas hídricas passaram, ao longo do tempo, a compor um processo mais amplo de gestão das águas. No Brasil, as políticas de recursos hídricos ganham contornos diferenciados a partir da promulgação da Constituição Federal de 1988. Nela se estabelece a dominialidade pública da água. Esse importante princípio constitucional substitui o Código de Águas, de $1934^{18}$, e extingue as chamadas "águas particulares".

Após a Constituição, alguns estados iniciam a elaboração de legislações específicas, construindo arranjos político-institucionais para a gestão das águas. Nesse contexto, o Ceará antecipa-se e elabora sua "Lei das Águas" (Ceará, 1992: Lei Estadual 11.996, de 24 de julho de 1992) ${ }^{19}$, em consonância com os princípios de descentralização, integração e participação social. A participação constante na lei deu origem aos Comitês de Bacia Hidrográficas, um colegiado formado setorialmente por representantes do "poder público", dos "usuários de água" e da "sociedade civil". Além disso, o novo arcabouço normativo definiu uma priorização de usos, resguardando como prioritários o consumo humano e a dessedentação animal. A água torna-se um bem público, dotado de valor econômico.

Componente fundamental da gestão das águas no Ceará, a alocação de água configura um aspecto central para os interesses do presente estudo. Fruto dos inúmeros conflitos e pressões vivenciados no estado no ano de 1993, período de grave crise hídrica, a alocação caracterizou-se como uma medida adotada por técnicos da COGERH para abrandar tais conflitos ${ }^{20}$. o Ceará havia recorrido à transferência de água da região jaguariba$\mathrm{na}^{21}$ para atender ao abastecimento urbano da sua capital, Fortaleza, gerando uma série de protestos e críticas. Questionava-se a "priorização" do consumo da "capital", em detrimento dos usos existentes no "interior".

A "alocação negociada"22, como veio a ser denominada, representa um processo de mediação técnica sobre a partilha da água. É uma negociação política,

\footnotetext{
17. Souza Filho, 2011. Aquino, 2019.

18. 0 Código das Águas promoveu uma política nacional de disciplinamento, controle e uso das águas como recurso econômico estratégico para a geração de energia e industrialização, classificando as águas entre públicas, comuns e particulares.

19. A legislação nacional só seria publicada em 1997 (Lei 9.433/97), instituindo a Política Nacional de Recursos Hídricos e o Sistema de Gestão Integrada de Recursos Hídricos - SIGERH.

20. Silva, Aquino e Souza Filho, 2013.

21. Região que concentra a bacia hidrográfica do maior e principal rio do Ceará, 0 Jaguaribe.

22. Termo cunhado no Ceará para designar o processo de discussão pública da partilha de águas dos reservatórios do estado.
}

fundamentada em dados técnicos produzidos pela COGERH, na qual os atores sociais debatem e disputam as quantidades de água a serem disponibilizadas para múltiplos tipos de usos. Representou um elemento novo na gestão da água, pondo o Ceará num espaço de destaque no Nordeste brasileiro, reconhecido como eficiente gestor de águas.

A "alocação negociada" foi incorporada como prática de gestão, sem constar no aparato normativo regulador da política de águas do estado. Nele, é a Outorga de Direito de Uso a regulação formal do direito de água. A outorga configura uma alocação de longo prazo e integra os instrumentos de gestão. É uma autorização legal concedida pelo estado que permite aos indivíduos ou instituições utilizarem a água, em conformidade com especificações determinadas no ato discricionário.

A água, enquanto recurso de uso comum, exige uma normatização. Historicamente, os povos estabeleceram distintos acordos quanto aos usos de recursos comuns (commom pool resources). Tais acordos são heterogêneos, alguns perduram, outros fenecem frente aos conflitos e disputas. A chamada governança desses "recursos" parece ser compreendida sob duas perspectivas principais. Uma, alinhada com princípios liberais, de concepção utilitarista dos recursos e de seus usos, pressupõe o mercado como regulador. Outra defende o estado a frente dos processos de regulação, estabelecendo normas e procedimentos legais para seus usos. Ostrom ${ }^{23}$ apresentou, entretanto, uma terceira abordagem, a partir da análise dos processos colaborativos e comunitários implicados no uso de recursos comuns. Sob essa perspectiva, nem o mercado, nem o estado seriam as vias únicas para o estabelecimento de processos de governança. Seria possível pensá-los a partir de gestões compartilhadas, com os usuários dos recursos definindo formas próprias de regulação, estabelecendo acordos colaborativos.

No Ceará, a gestão das águas efetiva-se num arranjo institucional baseado em instituições como a COGERH e a Secretaria de Recursos Hídricos do Ceará - SRH e nos Comitês de Bacia e Comissões Gestoras de Sistemas Hídricos $^{24}$. Nesse caso, a gestão da água diz respeito à "água bruta", ou seja, a água não tratada. São as águas dos reservatórios, dos poços, rios, canais, adutoras,

\footnotetext{
23. Ostrom, 2011.

24. Comissões Gestoras de Sistemas Hídricos são espaços públicos formais de participação social na gestão de mananciais considerados "isolados", ou seja, não interligados em vales de rios. As Comissões Gestoras apresentam formação setorial, como os Comitês de Bacia. São elas responsáveis por deliberar, junto dos técnicos da COGERH, sobre como será a partilha das águas dos mananciais "isolados".
} 
aquíferos e nascentes, cuja dominialidade divide-se entre a União e os estados federados. No Brasil, não há águas de domínio municipal. A água tratada, ou potável, está sob a regulação de outra política, a do saneamento básico, cuja competência recai sobre municípios e concessionárias de água e esgoto ${ }^{25}$.

As políticas públicas de recursos hídricos e saneamento não são integradas. Suas conexões, no caso cearense, se estabelecem nas "reuniões de alocação de água", quando as concessionárias de saneamento figuram na posição de "usuárias" de água. O setor de recursos hídricos fornece a água a ser tratada e distribuída pelos municípios e concessionárias. 0 estado do Ceará instituiu, em 2016, sua política de abastecimento de água e de esgotamento sanitário, por intermédio da Lei Complementar $n^{\circ} 162$, de 20 de junho de 2016, a qual determina o acesso à água potável como direito humano.

Tal quadro reflete a complexidade do tema da água numa condição de semiaridez. No entanto, na região do Cariri, a problemática da água aparece como uma realidade peculiar ao restante do estado. A análise desse contexto pode trazer luzes sobre a relação entre escassez, abundância, gestão e conflito de águas.

\section{Um "Oásis" no Ceará? o Cariri e suas nascentes}

Presente em inúmeras representações sociais em torno de ideias de religiosidade e regionalismo, o Cariri é conhecido como uma região diferenciada do Ceará, dada sua formação histórica, suas características climáticas e geológicas e sua cultura. Situa-se a mais de $600 \mathrm{~km}$ de qualquer capital nordestina, incluindo a litorânea capital do Ceará. Ademais, o Cariri é perpassado por referentes de uma terra abonada em água e verde, opondo-se às imagens da seca e seus flagelos.

Um fator de diferenciação do Cariri é a conformação geológica do seu solo, no qual se formou uma bacia sedimentar com três sistemas de aquífero. Essa característica possibilita a existência de nascentes, que brotam entre 680 e 750 metros acima do nível do mar, no aquífero superior, existente na Chapada do Araripe (Mapa 2). A chapada é um enorme platô espraiado por três estados nordestinos, Ceará, Pernambuco e Piauí. o lado

\footnotetext{
25. 0 Brasil encontra-se, atualmente, em processo de redefinição do marco regulatório do saneamento, debate centrado na polêmica abertura desses serviços essenciais à iniciativa privada (Projeto de Lei 4.162/2019 da Câmara dos Deputados).
}

cearense concentra o maior número de nascentes, 272, das 394 fontes cadastradas.

Do ponto de vista hidrográfico, o Cariri é o território da Sub-bacia Hidrográfica do Rio Salgado, afluente do principal rio do Ceará, o Jaguaribe. Em comparação com a totalidade da área da sub-bacia, a bacia sedimentar representa uma parcela diminuta, conforme demonstram os mapas 3 e 4.

Além disso, apenas seis dos vinte e três municípios que formam a sub-bacia possuem nascentes: Crato, Barbalha, Missão Velha, Porteiras, Jardim e Brejo Santo. As fontes com maiores potenciais de vazão concentram-se em Crato, Barbalha e Missão Velha ${ }^{26}$. Assim, a ideia de "oásis" entra em desacordo com o fato de predominar na região as chamadas "terras secas", nas quais foram construídos quinze reservatórios, sendo esses as principais reservas hídricas dos municípios.

A imagem de abundância hídrica condiz muito mais com um imaginário construído na região. A ideia do Cariri como território diferenciado das condições de seca passou a figurar como elemento fundante de uma identidade regional. Essa representação é fruto de uma construção histórica, motivada por interesses da classe senhorial em justificar o uso agrícola da terra e das águas para a produção de cana de açúcar, no século XIX. Nesse contexto, haveria uma suposta "vocação natural" para a agricultura, dada a "abundância" de água ${ }^{27}$, constituindo-se uma representação do Cariri como "oásis do sertão".

Contudo, a disponibilidade hídrica, caracterizada pela presença de nascentes perenes, não significa acesso e distribuição equânimes da água. As representações sobre uma terra de abundância não devem escamotear o fato de a água não necessariamente atender a todas as demandas e necessidades. Fato aliás marcante em outras situações e lugares.

Em estudo acerca do abastecimento de São Paulo no século XIX, Sant ${ }^{\prime}$ nnna $^{28}$ aborda uma cidade entrecortada por muitos rios e fontes de água, não obstante enfrentasse inúmeros conflitos e disputas pelo "precioso líquido”. A "cidade das águas" também era seca, com numerosos problemas na rede de abastecimento. $\mathrm{Na}$ disputa pela água, os mais pobres eram os mais vulneráveis.

Outro estudo aborda aspectos semelhantes quanto ao século XIX. Diniz ${ }^{29}$ analisa duas cidades portuárias,

\footnotetext{
26. Sabiá, 2000 .

27. Reis Junior, 2014.

28. Sant'Anna, 2007, 27.

29. Diniz, 2014.
} 
Mapa 2. Localização da Chapada do Araripe

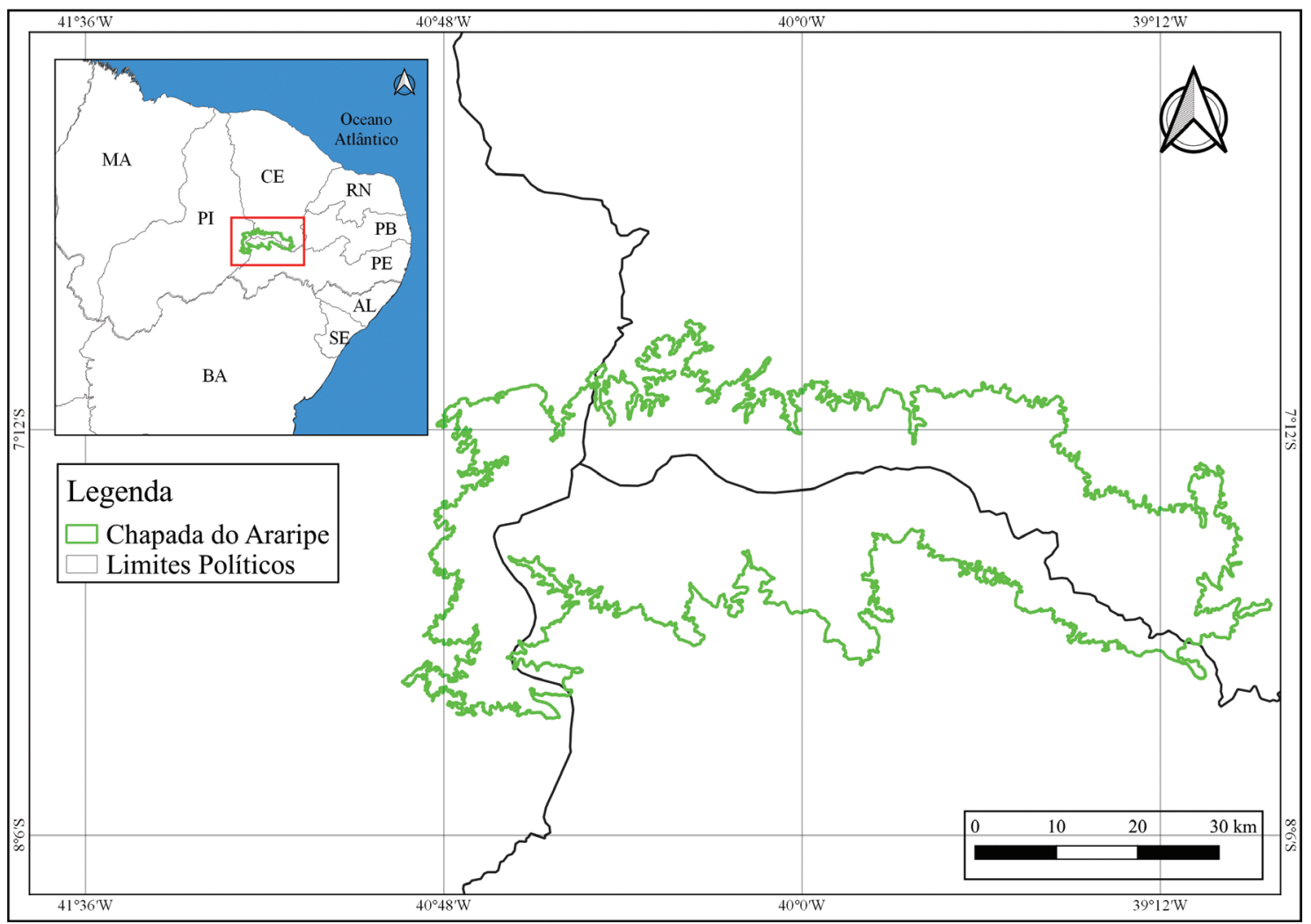

Fonte: Elaboração própria, 2020

Mapa 3. Sub-bacia Hidrográfica do Rio Salgado

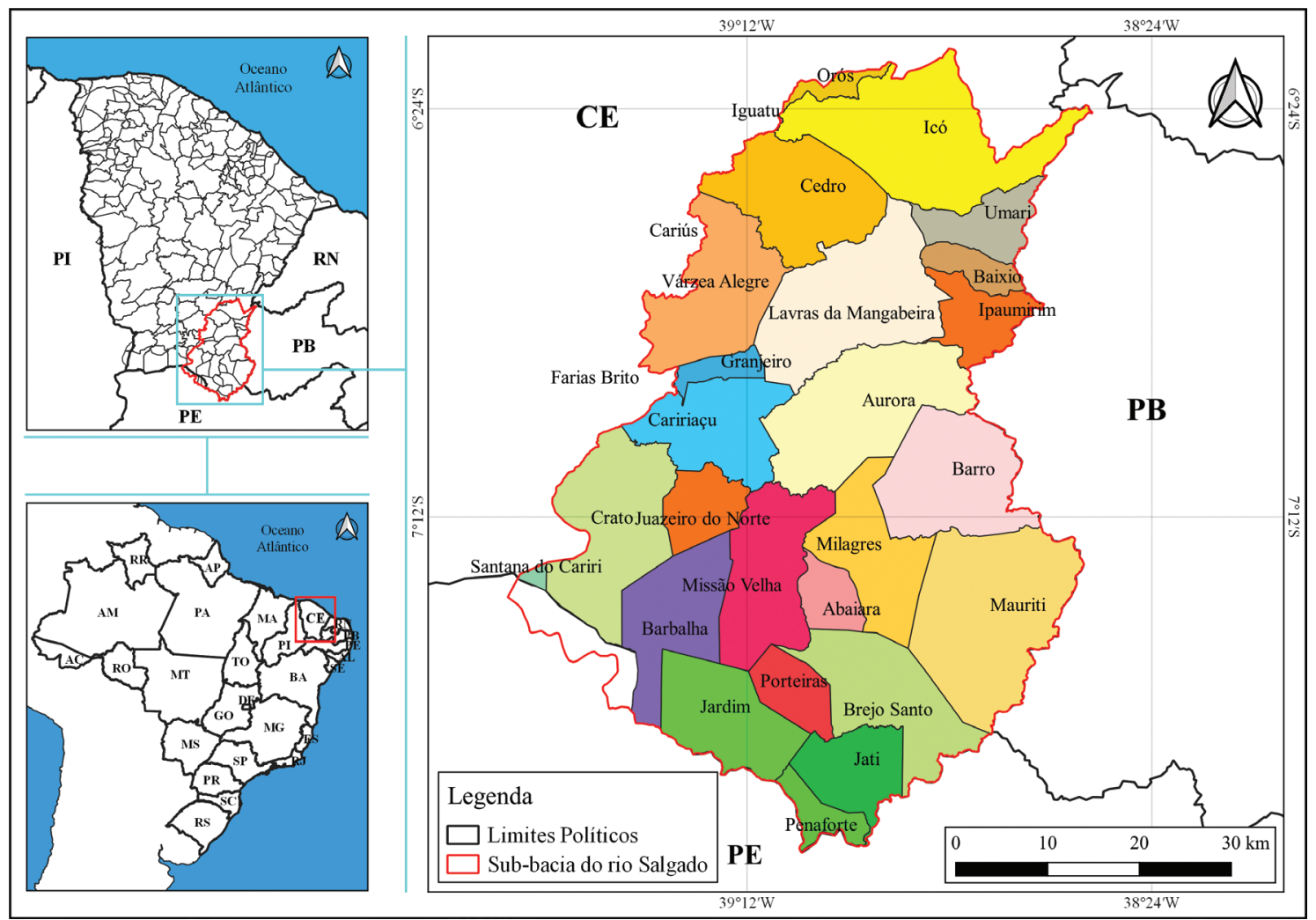

Fonte: Elaboração própria, 2020. 
Mapa 4. Bacia Sedimentar do Araripe

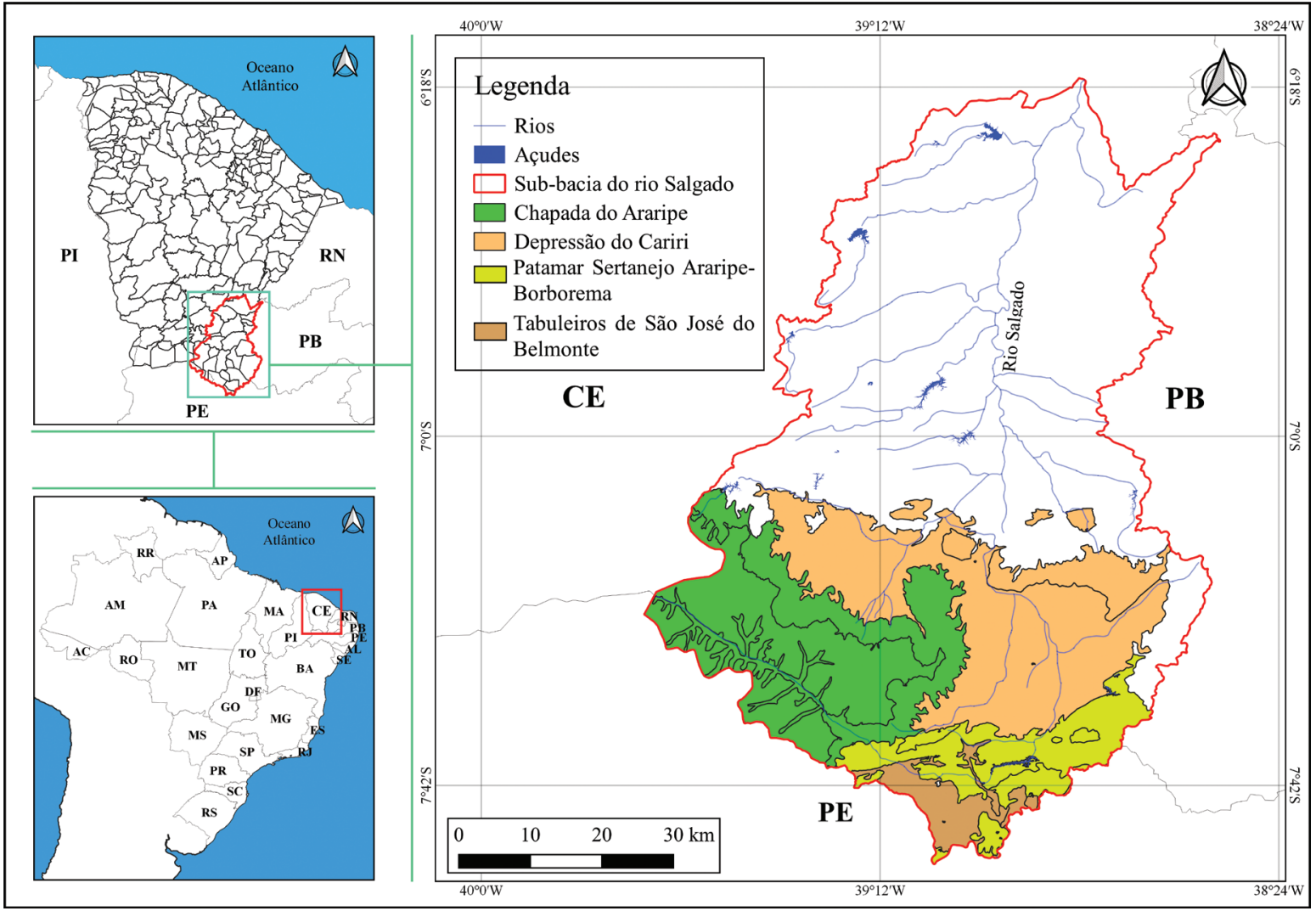

Fonte: Elaboração própria, 2020

Aracati, no Brasil, e Lüderitz, na Namíbia. Nelas, a existência de fontes hídricas não garantia o abastecimento de todos os grupos sociais. Aracati, no sertão cearense, vivia entre a escassez e a abundância das águas do Rio Jaguaribe. As cheias do rio poluíam as fontes de água potável e destruíam os sistemas de abastecimento. Além disso, a proximidade com o mar tornava suas águas salgadas. Os mais abonados construíam poços particulares, restando aos demais encontrar tecnologias alternativas e de baixo custo para reservar água ou utilizar as fontes públicas disponíveis, muitas vezes contaminadas. Incluía-se, nesse contexto, a compra de água, o transporte no lombo de animais, em carroças ou nos braços humanos (de mulheres, crianças e escravizados), formas históricas de "solução" para os problemas de abastecimento.

Logo, os dilemas em torno da água e seus manejos sinalizam complexas relações entre sociedade e natureza, permeadas por conflitos, tensões e disputas nas formas de apropriação de recursos e bens naturais dos territórios, como assegura Acselrad ${ }^{30}$. Não é de estranhar que a região Norte do Brasil, onde se concentram as maiores reservas de água doce do país, apresente os piores

\footnotetext{
30. Acselrad, 2004.
}

indicadores de abastecimento de água potável entre as regiões brasileiras. Nessa região, em relatório do ano de 2017, 42,5\% municípios não dispunham de redes seguras e permanentes de abastecimento de água potável ${ }^{31}$.

\section{Contendas pela água. Disputas na gestão das águas das nascentes no Cariri}

Os conflitos são processos sociais imbricados nas relações humanas e constituem um aspecto fundamental da mudança social, segundo a ótica consagrada na análise marxista. Simmel ${ }^{32}$, desde outra perspectiva, nos ajuda a pensar as situações de conflito, considerandose seus aspectos negativos e positivos. A contradição e o conflito são fatos inerentes à vida em sociedade. São, na verdade, tipos diferentes de interação. Assim, conflitos não são apenas vetores de processos destrutivos, mas tornam visíveis os cenários de violência, injustiças, oposições e contradições.

A água, nesse sentido, nos conduz a pensar sob a ótica dos conflitos socioambientais, exatamente aqueles

\footnotetext{
31. Diagnóstico dos Serviços de Água e Esgoto - Sistema Nacional de Informação sobre Saneamento (SNIS), 2017.

32. Moraes Filho, 1983, 59-86.
} 
derivados de "modos de apropriação, uso e significação do território" 33 . Isso porque apesar de um elemento vital e direito humano fundamental, a água não se distribui com equidade nos territórios, nem entre os diversos atores sociais. Ao contrário, existem usos hegemônicos nas formas de apropriação e controle das águas, que ajudam a compreender noções de escassez e abundância para além dos aspectos físicos e naturais.

Os conflitos portam conteúdos políticos e se manifestam por vezes de formas sutis, construídas nas interações entre os diversos atores em disputa pelos "recursos" existentes. Nessas disputas, cada ator acessa o seu próprio cabedal de estratégias e de capital, seja para garantir acesso ou para constranger determinados usos. Os múltiplos capitais (econômico, social, cultural, material) são acionados diferentemente pelos atores na contenda.

Mais visíveis nos quadros de seca, os conflitos pela água não são recentes, nem surgem de repente. Não são exclusivos de regiões semiáridas, apesar da condição de escassez relativa agudizar os problemas associados aos processos de apropriação da água. Conflitos, nesse caso, são a expressão de interesses distintos e tensões entre os atores quanto às formas diferenciadas de controle $\mathrm{e}$ acesso à água ${ }^{34}$.

No Cariri, os conflitos ganham matizes singulares e feitios ainda mais complexos, tendo em vista a forma como foi historicamente ocupado o território da Chapada do Araripe. Essa ocupação transformou extensas áreas verdes em propriedades agrícolas. Surgiram pequenos sítios e comunidades de caraterísticas rurais. A água das nascentes chegava às propriedades agrícolas e às comunidades por meio de "levadas", uma espécie de canal artesanal. Assim, o curso natural das águas era alterado e estas chegavam ao seu destino por força da gravidade e pelo trabalho do "levadeiro" 35 .

Mesmo perenes, as nascentes apresentam uma dinâmica muito variável entre um ano e outro, estando intimamente relacionadas com as precipitações pluviométricas. Os anos e décadas com menores índices de chuva têm como consequência menores vazões das nascentes. Assim, não há garantia permanente de suprimento para todos os usos existentes, favorecendo o surgimento de conflitos pela água.

\footnotetext{
33. Acselrad, 2004.

34. Orellana-Gavidia, 2013, 28.

35. Levadeiro era a pessoa contratada para realizar um serviço de distribuição das águas e manutenção das levadas. Seu trabalho visava controlar as horas e dias das águas entre as várias propriedades, fechando uma parte da levada para o líquido correr em outra, de acordo com o que definiam os documentos cartoriais.
}

Ao longo do tempo, todo um repertório de ações, técnicas, manejos e instrumentos destinados à gestão das águas foi construído a partir de muitas mãos e olhares. A "alocação negociada" é um deles. Contudo, entre a alocação de um reservatório superficial, como um açude, e a de nascentes há diferenças e níveis diversos de complexidade. A construção de um reservatório implica em desapropriação das terras a serem alagadas e indenização aos antigos proprietários e moradores. Isso não ocorre no caso das nascentes. Situadas em propriedades de domínio privado e marcadas por usos históricos de suas águas, as fontes são em número elevado e dispersas no território. Descontínua é também a localização dos moradores e irrigantes. A água, em geral, escoa por força gravitacional a cada residência ou área de cultivo agrícola. Assim, há um certo privilégio de quem mora ou produz nas áreas mais próximas das nascentes, enquanto os mais distantes recebem a água num fluxo e volumes menores.

Assim, a análise dos registros e a observação das reuniões para mediação de conflitos possibilitam uma visão geral dos problemas vivenciados nos usos, acessos e entendimentos acerca da gestão dessas águas, sintetizados abaixo:

- Usos históricos e novos usos da água na Chapada do Araripe - "os donos da água"

- Competição por fontes hídricas cada vez mais escassas

- Associação entre terra e água

- Usos humanos e a preservação ambiental das nascentes.

\section{Usos históricos das nascentes e suas repercussões atuais: os "donos" da água}

No Brasil do século XIX, o controle e a legislação das águas estavam sob a tutela do poder local, com a elaboração de Códigos de Postura e documentos cartoriais ${ }^{36}$. Nesse aspecto, verifica-se na região do Cariri uma forma de partilha de água semelhante a um mercado de águas ${ }^{37}$. A água era então vendida e comprada utilizando-se como medida a "telha d'água" ${ }^{38}$. Nessa transação comercial, cada "dono" recebia seu quinhão de água, dividido em horas e dias. Essa experiência teve como embrião o município do Crato e se deu a começar em sua principal nascente, a Batateira. Originou-se a partir da

\footnotetext{
36. Diniz, 2014.

37. Kemper, Gonçalves \& Bezerra, 1999

38. Telha é uma medida de água portuguesa, adotada no Cariri, no século XIX.
} 
emergência de conflitos pela água entre os produtores de cana-de-açúcar, matéria-prima do principal produto econômico da época, a rapadura.

o plantio da cana era realizado com uso da água das nascentes. $O$ aumento da demanda da rapadura no mercado local conduziu à implementação de mais áreas de cana, ampliando o consumo de água e intensificando os conflitos por sua partilha. Em 1855, os produtores locais recorreram ao presidente da província do Ceará, Joaquim Villela de Castro Tavares. Este editou uma Resolução Provincial (Lei no 645 de 17 de janeiro de 1854) como um acordo entre os produtores, dando origem a um Auto de Partilha das Águas do Rio Batateira ${ }^{39}$. 0 então juiz substituto da Comarca do Crato, Afonso de Albuquerque e Melo, estabeleceu o referido auto, assinado pelos interessados em cartório público, sendo a água da fonte repartida em 23 "telhas".

Desde então, os proprietários garantiam em cartório o "direito de água", considerando-se seus "donos" legais. 0 controle sobre as fontes de água expressava o domínio econômico e social dos segmentos mais abonados da região ${ }^{40}$, sobretudo por estarem as nascentes situadas no interior de propriedades particulares. Portanto, a posse da terra estava em estreita associação com a posse da água. Essa prática espalhou-se por outros municípios da região, com novas partilhas das "telhas" de água. A comercialização das águas vigorou por mais de 100 anos e começou a ser questionada com a mudança do regime de dominialidade da água, estabelecida pelo novo ordenamento jurídico brasileiro, no século XX.

Não obstante a radical alteração da dominialidade da água, estabelecida na Constituição, os antigos documentos e as expectativas do "direito adquirido" perduram nas práticas e discursos. Acordos e usos rotineiros mantiveram-se numa forma de gestão e controle própria à região, estabelecendo usos compartilhados entre "donos" das águas e comunidades. Tal realidade se viu ameaçada pelo crescimento populacional, pela diversificação de atividades econômicas e pela redução de vazões das nascentes da Chapada do Araripe. A menor quantidade de água disponível ensejou uma maior pressão por novas partilhas, dando origem a outros conflitos.

Diante disso, um processo de alocação de águas promovido pelo estado, ancorado nos novos preceitos legais e coordenado pela COGERH, visou a proceder a regularização dos diversos usos da água, por meio da outorga de

\footnotetext{
39. Sobre o caso da Fonte Batateira ver Kemper, Gonçalves \& Bezerra,1999. Viana e Costa, 2015. Hissa, 2005. Santos, 2014. Sabiá e Frischkorn, 2004

40. Reis Junior, 2014.
}

direito de uso, a partir dos anos 2000. Nesse tocante, os antigos proprietários ou "donos" das águas, foram incentivados pelos técnicos da COGERH a solicitarem a outorga. Assim, o proprietário, ou outorgante, passou a ter as suas "horas e dias de água" convertidos em vazões contínuas, "regularizando" a sua condição de uso. Esse procedimento contribui para atenuar conflitos, pois permitiu novos usos, mas manteve as águas predominantemente nas mesmas mãos. Isso contribuiu para a emergência de novas situações de disputa, discutidas na sequência do texto.

\section{Competição por fontes hídricas cada vez mais escassas}

A representação da abundância de água permeia o convívio das comunidades rurais e das áreas urbanas com as nascentes no Cariri. Como atesta Acselrad ${ }^{41}$, a interface entre o mundo social e sua base material é atravessada por diferentes práticas, sejam elas técnicas, sociais ou culturais, atuando nessas últimas esquemas de percepção diferenciados. Os usos das águas não se reduzem às estruturas físicas e redes técnicas, mas são também demarcados por simbolismos e representações. No Cariri, o fluxo contínuo da água e sua gratuidade forjaram a ideia de infinitude desse bem, com impactos nas formas de uso.

Paralelamente a essas representações, as encostas da Chapada do Araripe têm observado um intenso processo de uso e ocupação. Áreas de produção agropecuária, casas de veraneio, além de inúmeros balneários instalaram-se na região. É a água das nascentes a única fonte hídrica para todos esses múltiplos usos. Mais que isso, as nascentes são responsáveis pelo suprimento de água potável das comunidades rurais e de algumas zonas urbanas. Assim, a disputa pela água se intensifica, demandando do estado estratégias e propostas de solução para os conflitos.

$\mathrm{Na}$ área rural, onde se localizam várias pequenas comunidades, a maioria dos domicílios não dispõe de caixas d'água para armazenar o líquido, nem sistemas públicos de abastecimento. Cada família responde por seu próprio provimento. Incomuns são os sítios onde existe sistema comunitário de água. Nesse caso, as associações de moradores organizam projetos e buscam, por sua conta, solucionar os problemas de abastecimento, dada a omissão do poder público municipal. Essa situação não é rara no Nordeste brasileiro como um todo ${ }^{42}$.

\footnotetext{
41. Acselrad, 2004.

42. Silva et al., 2012.
} 
Os aspectos abordados produzem um quadro dos problemas enfrentados pelas populações no acesso à água potável, reconhecido pela ONU, em 2010, como um direito humano fundamental. Via de regra, o serviço de saneamento básico, no tocante à água, trilha o caminho das soluções alternativas. Nas áreas rurais do Brasil são 3,3 milhões de brasileiros sem acesso adequado ao abastecimento de água ${ }^{43}$. No Cariri, mais particularmente nos municípios de Crato e Barbalha, os problemas de abastecimento de água nas comunidades rurais são mais evidentes. Neles, a existência das nascentes permitiu aos gestores municipais atuar, ao longo dos anos, de forma negligente quanto às questões prementes de saneamento. Afinal, água não era problema.

Contudo, a redução das vazões, verificada na última década, e o crescimento no número de moradores, impede a água de chegar em todas as localidades. Os moradores buscam soluções individuais, como canos e mangueiras de borracha, colocados, de forma improvisada, diretamente nas nascentes. A forma desordenada de captação compromete a distribuição da água, gera problemas ambientais e provoca inúmeros conflitos. Nessa competição ganham os mais fortes, os mais próximos da água ou os que burlam acordos estabelecidos coletivamente sobre a sua partilha.

No município de Barbalha, a Prefeitura Municipal paga funcionários para fazer a distribuição das águas nas fontes com maiores vazões e conflitos. O funcionário faz o manuseio dos canos e mangueiras nos locais de captação, atendendo ora a uma comunidade, ora a outra. Para os gestores municipais, a água deveria ser disponibilizada gratuitamente aos cidadãos de Barbalha. Porém, a forma improvisada, irregular e desordenada agrava as tensões existentes e os problemas ambientais ocasionados com a canalização das nascentes.

Ademais, instalações hidráulicas precárias são regra nos usos agropecuários. São também muito presentes os métodos rudimentares de irrigação. A agricultura responde por $70 \%$ do consumo da água das nascentes. $\mathrm{O}$ irrigante é, em geral, morador das comunidades rurais. Porém, alguns deles residem nas áreas urbanas dos municípios e portam outorgas de uso, como no passado portaram títulos cartoriais de propriedade.

Nas comunidades rurais há uma pulverização de tensões em torno das diversas finalidades de uso. Dentre elas situam-se os usos das nascentes para a centenária prática da lavagem de roupa, predominante entre mulheres residentes em comunidades rurais onde não há

\footnotetext{
43. Brasil, 2013
}

sistemas de abastecimento de água instalados. As instituições ambientais combatem essa prática, por considerarem-na fonte de poluição das águas. A água, após a lavagem de roupa, desce para os demais usos, inclusive humanos, com os resíduos dos produtos de limpeza.

Algumas das reuniões realizadas pela COGERH foram solicitadas por um grupo de lavadeiras de roupa do Crato, que se julgavam prejudicadas pela instalação de um sistema de distribuição de água para regularizar usuários outorgados. $O$ equipamento reduziu o fluxo da água da nascente, impedindo a lavagem de roupa. As mulheres reivindicavam a liberação de mais água, pois algumas dependem financeiramente dessa atividade. Como solução proposta, a COGERH criou uma comissão gestora, com representação das lavadeiras. A comissão tem caráter formal e tem se efetivado como espaço de discussão e negociação dos problemas relacionados aos usos da água da nascente.

Conflitos são também observados nos usos para o lazer, com a presença de vários balneários e parques aquáticos na região. Nesse caso, as águas das nascentes enchem piscinas e toboáguas e, em seguida, atendem comunidades e irrigantes. Como o uso nos balneários se intensifica aos finais de semana, há uma redução da água para os sítios a jusante, provocando muitas contendas entre donos de balneários, comunidades e irrigantes. Os balneários consolidaram-se como importante atividade turística e de lazer no Cariri e disputam as águas existentes.

\section{Propriedade privada versus água pública}

Estando as nascentes localizadas em áreas privadas, o acesso à água submete-se à autorização e aos interesses dos proprietários, muitos deles antigos "donos" de água. A legislação criou o caráter público da água, mas não tocou nas questões prementes da propriedade da terra e do acesso aos mananciais. Tal fato tem sido vetor de inúmeros conflitos e de situações de desabastecimento de algumas localidades.

Um caso crítico desse problema ocorreu na zona rural do município do Crato, entre a Comunidade Guaribas e o dono da propriedade na qual se localiza a nascente Guaribas, no ano 2000. A comunidade, formada à época por 82 famílias, aprovou, por intermédio de sua associação, recursos públicos para implantação de um sistema comunitário de abastecimento de água. Mas o proprietário não autorizou a construção da obra. Isso deu origem a uma longa luta judicial. A associação comunitária, mesmo com a posse da outorga de direito de uso, perdeu a causa e não concretizou o projeto de abastecimento. O conflito teve seu momento mais grave no ano 2006, 
quando foi necessária a devolução ao estado do recurso obtido, em vista da não realização da obra ${ }^{44}$.

Tal fato tem ocorrido mais recentemente em outras situações e comunidades, como a disputa pelo acesso à água da Nascente Cocos, em 2016, no município de Barbalha. 0 proprietário do terreno, e principal usuário da fonte, danificou os canos instalados para o abastecimento de famílias e irrigantes outorgados. Foram necessárias várias reuniões para finalmente ocorrer a instalação do sistema de distribuição. Ou seja, a regularização é condição necessária, mas não suficiente para acessar os serviços de água ${ }^{45}$.

A alocação das águas das nascentes apresenta um elemento de alto potencial de conflitos e demonstra a permanência de usos privados da água. Nas reuniões realizadas com esse intuito fica evidente que o caráter público da água, por si só, não é suficiente para a garantia dos múltiplos usos. Mesmo o abastecimento público da cidade do Crato, feito pela SAAEC - Sociedade Anônima de Água e Esgoto do Crato, depende da anuência dos proprietários de terras para a instalação e manutenção das redes do sistema de distribuição. Dessa maneira, as formas de ocupação e apropriação do território permanecem como fatores capazes de interferir nos usos e no acesso à água.

\section{Uso humano versus preservação das nascentes - o caso do soldadinho-do-araripe}

O ambiente das nascentes da Chapada do Araripe, mais precisamente da Área de Proteção Ambiental ${ }^{46}$ é o hábitat de uma ave endêmica à região do Cariri, o soldadinho-do-araripe (Antilophia bokermanni), espécie descoberta por ornitólogos em 1996. Mesmo com o registro relativamente recente de sua existência, o soldadinho-do-araripe enfrenta perigo semelhante ao de muitas espécies silvestres, o risco de extinçãa ${ }^{47}$.

A ave sobrevive exclusivamente em nascentes em bom estado de conservação, ou seja, nascentes com vegetação preservada e sem canalização do curso d'água. De acordo com o Plano de Ação Nacional para a Conservação do soldadinho-do-araripe ${ }^{48}$, a vegetação presente nas nascentes está relacionada ao ciclo reprodutivo do

\footnotetext{
44. Souza, 2008.

45. Castro, 2016, 42

46. Existem na Chapada do Araripe duas Unidades de Conservação, a Área de Proteção Ambiental - APA Chapada do Araripe e a Floresta Nacional do Araripe - Flona, ambas unidades federais, gerenciadas pelo Instituto Chico Mendes de Conservação da Biodiversidade - ICMBio. A APA é formada por propriedades privadas, enquanto a Flona tem uso restrito. Ambas têm implicações diretas na existência das nascentes.

47. ICMBIO, 2011, 09.

48. ICMBIO, 2011.
}

pássaro. Porém, a ocupação desordenada das encostas da chapada e as formas de captação e distribuição precárias da água têm se configurado um problema para a sobrevivência do pássaro, pois transformam nascentes e levadas em terras secas.

A canalização das nascentes tem sido a forma encontrada por muitos usuários para garantir seu abastecimento de água. A exemplo do que ocorre na Ilha de Amantaní, no Peru ${ }^{49}$, a distribuição da água depende da geografia do lugar. Sem os canos e mangueiras, a água não consegue atender aos múltiplos usos, gerando um paradoxo: uso humano ou preservação ambiental. 0 impasse torna-se objeto de discussões e debates entre os atores envolvidos, cujos argumentos manifestam visões divergentes sobre os usos legítimos ou prioritários das águas.

O soldadinho-do-araripe tornou-se emblemático para a preservação e conservação das nascentes na região. Ele tem sido tema de debates públicos no Comitê de Bacia, nas Comissões Gestoras de Fontes e nas organizações ambientalistas. Os ambientalistas argumentam sobre a relação entre o pássaro e a sustentabilidade ambiental e os demais usuários asseveram a prioridade dos usos humanos. Segundo os ambientalistas da região, enquanto perdurarem as atuais formas de uso, acesso e controle das águas, a vida do pássaro e a preservação das nascentes estarão ameaçadas.

\section{As Soluções apontadas pelo estado na "Mediação dos conflitos"}

O processo de mediação dos conflitos relativos aos usos das águas no Ceará baseia-se no princípio da participação pública, tendo como um dos atores centrais a COGERH. Diante dos dilemas vivenciados no cotidiano de usos das nascentes, os técnicos da COGERH realizam, dentre outras atividades, "reuniões para mediação de conflitos". Os acordos e negociações produzidos nas reuniões são documentados em atas.

Para ocorrer uma reunião é preciso manifestação de interesse, denúncia ou solicitação por parte do interessado. Em geral, são as comunidades rurais as maiores demandantes da intervenção do estado, para mediar situações de descumprimento de antigos acordos, e, sobretudo, para barganhar acesso às águas. Esse processo nem sempre é rápido e os objetivos e interesses dos demandantes não necessariamente chegam a um bom termo.

49. Orellana-Gavidia, 2013. 
A Gerência Regional da COGERH na Sub-bacia do Salgado registrou em ata, entre janeiro de 2014 e fevereiro de 2016, 48 reuniões com "usuários" de nascentes $^{50}$, sendo 25 no município do Crato, 21 em Barbalha e 2 em Jardim. Contudo, muitas das reuniões não são registradas em atas. 0 registro normalmente só ocorre para "formalizar" acordos e entendimentos entre os usuários. Observa-se no Quadro 1 o número superior de reuniões em relação ao registrado em atas, chegando a 89 reuniões relacionadas a 26 nascentes.

Ao contrário da gestão da água superficial, foco de maior atenção das instituições de recursos hídricos no Ceará, a gestão da água subterrânea é um desafio, dada a maior complexidade do monitoramento. $\mathrm{O}$ quadro de técnicos da COGERH é reduzido e o conhecimento sobre os mananciais de água subterrânea é ainda deficitário. Assim, a COGERH não consegue responder a contento as demandas e conflitos existentes. Os processos de gestão dependem da abertura para arranjos mais informais de compartilhamento e definição de regras de uso ${ }^{51}$, mas esbarram nos preceitos formais.

As alternativas utilizadas com vistas à resolução dos conflitos e à partilha das águas das nascentes têm sido a realização de reuniões de alocação para estabelecimentos de acordos e regras de partilha, a constituição de espaços mais formalizados de organização (como as comissões gestoras), a regularização dos usos por meio de outorga e uma solução técnica denominada "barrilete" (Figura 1).

\section{QUADRO 1. SÍNTESE DAS ATIVIDADES RELATIVAS ÀS NASCENTES DO NÚCLEO DE GESTÃO DA COGERH, 2014-2016}

\begin{tabular}{|c|c|c|c|c|}
\hline Síntese das informações do Núcleo de Gestão/Ano & 2014 & 2015 & 2016 & Total \\
\hline Total de reuniões & 27 & 25 & 37 & 89 \\
\hline Reuniões mediação de conflitos & 17 & 9 & 25 & 51 \\
\hline Mobilizações & 8 & 11 & 28 & 47 \\
\hline Atividades com Comissão Gestora de Fontes & 6 & 14 & 12 & 32 \\
\hline Total de fontes relacionadas & 15 & 15 & 16 & $26^{*}$ \\
\hline
\end{tabular}

Fonte: elaboração própria a partir dos relatórios de atividades da COGERH.

* As fontes não são necessariamente distintas de um ano a outro, o que impede uma mera soma dos três anos. Ao todo foram discutidos problemas relacionados a 26 nascentes.

Figura 1. Barrilete

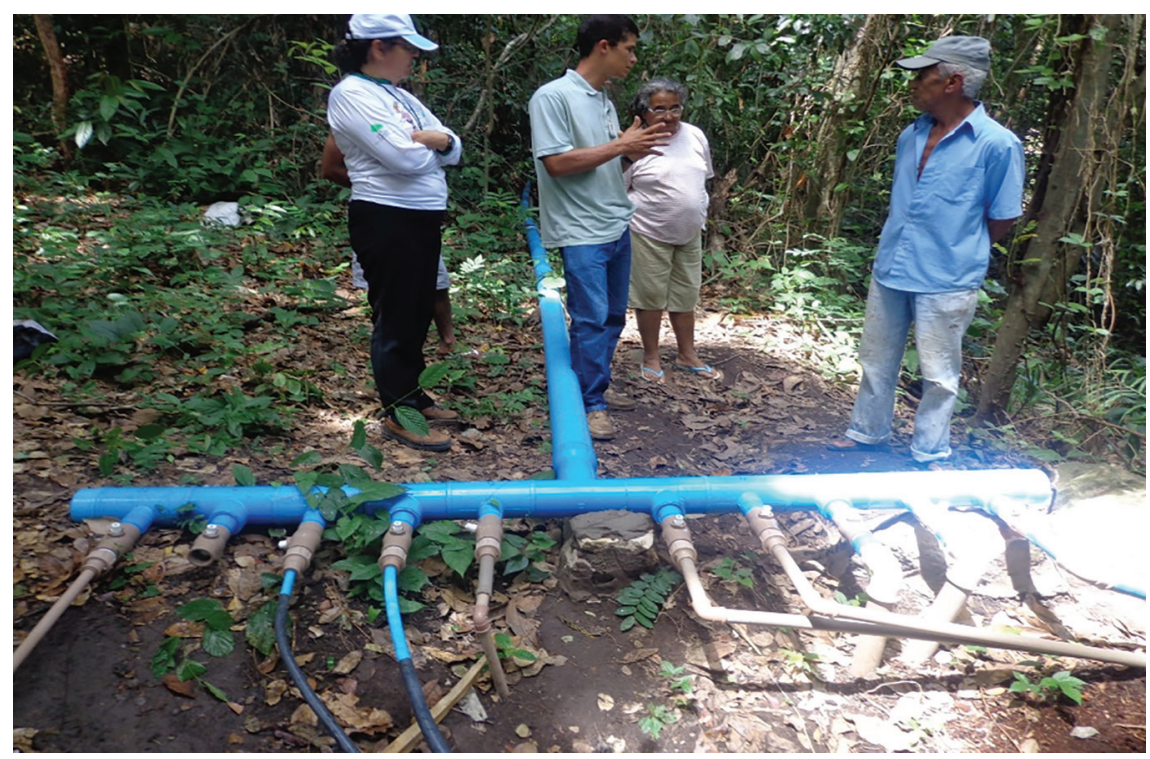

Fonte: COGERH, 2014

\footnotetext{
50. No jargão utilizado na legislação e nos discursos técnicos a população é classificada por termos genéricos, como "usuários", "consumidores" (Castro, 2016).
}

\footnotetext{
51. Ostrom, 2011.
} 
Em geral, a postura do estado frente às situações de conflitos por água ou outros bens naturais consiste em tentar atenuá-los, promovendo acordos e, sobretudo, construindo consensos. Os conflitos são assim percebidos, destacam Acselrad e Moulier-Boutang ${ }^{52}$, como algo a ser evitado ou solucionado. São considerados um erro a ser corrigido. Essa perspectiva perde de vista a positividade existente nos conflitos, por trazerem à baila inquietações e recusas quanto às apropriações de um bem necessário a todos, e não vai a fundo nas questões em disputa, especialmente nas relações entre terra e água.

Assim, vigoram as soluções técnicas, como o barrilete. Elas captam a água numa tubulação única e a distribuem de acordo com as outorgas. Essa resposta tem se tornado padrão, sendo demandada por várias comunidades. Para muitos, consiste numa resolução de baixo custo para os problemas urgentes. Entretanto, apresenta alguns limites: nem sempre consegue respeitar a legislação ambiental ${ }^{53}$; as vazões das nascentes oscilam, alterando o funcionamento do barrilete; os custos da obra são financiados pelas famílias e demais usuários das águas.

Além disso, todos os "usuários" precisam estar outorgados para só então os barriletes serem instalados, em conformidade com as determinações de cada documento. Porém, esse processo não é simple. Os usos são difusos e não há condições técnicas para instalar aberturas no barrilete em consonância com cada demandante em particular. Isso exige uma articulação entre os atores para solicitar outorgas coletivas, nem sempre possível ou desejado. Também não são raros os danos às estruturas hidráulicas causados por quem se julga prejudicado pela forma de partilha. Alguns barriletes funcionam bem por vários meses, mas não é incomum apresentarem algum dos problemas elencados.

Para a COGERH, sua responsabilidade concentra-se "do barrilete para cima", ou seja, na captação da água e na organização da partilha no barrilete. A distribuição, "do barrilete para baixo", recai sobre municípios, comunidades e demais usuários das águas. $\mathrm{Na}$ divisão de funções entre as políticas de recursos hídricos e de saneamento básico, a COGERH entende que a distribuição da água compete à segunda, não configurando um problema de "gestão de recursos hídricos".

\footnotetext{
52. Acselrad, 2004. Moulier-Boutang, 1999.

53. A Legislação ambiental no Brasil prevê uma distância mínima de 50 metros para qualquer intervenção na área de proteção das nascentes.
}

\section{Reflexões finais}

As reflexões deste estudo dão conta dos dilemas em torno da gestão da água de nascentes no Cariri, área do semiárido brasileiro onde se constituiu um imaginário de abundância hídrica, modelando formas como comunidades rurais e urbanas se relacionam com as águas. Tomamos o Cariri cearense como caso emblemático para se analisar as interfaces entre disponibilidade hídrica e acesso à água e as estratégias do estado para promover processos de negociação e mediação de conflitos.

O estudo demonstra que tanto a disponibilidade quanto a escassez hídrica estão intimamente associadas às formas de apropriação social da água, não sendo explicáveis unicamente por fatores climáticos ou hidrológicos. A garantia de oferta hídrica, pensada como a solução para o semiárido, não elimina os fatores de ordem econômica, social, política e cultural atuantes nas formas de apropriação e uso da água numa sociedade desigual.

Ademais, a análise da realidade do Cariri cearense permite uma reflexão acerca do lugar das comunidades difusas no tocante aos serviços de abastecimento de água nas zonas rurais do semiárido brasileiro. Nessas áreas prevalecem as resoluções individuais, associativas e padronizadas, indicando o quão distante está a conquista plena do direito humano à água, mesmo em regiões supostamente mais bem providas desse bem. 0 abastecimento das comunidades rurais no Cariri revela como os problemas existentes se agravam com a implementação setorial das políticas de recursos hídricos e de saneamento, fragmentando processos de gestão, partilha e decisão entre "água bruta" e "água tratada".

O estudo também atesta a relevância da politização do tema da água e dos conflitos atinentes, retirando-a do campo restrito das discussões técnicas. A maior diversificação observada nos usos das nascentes do Cariri, nos últimos anos, relaciona-se à publicização desses conflitos. Com o novo marco jurídico brasileiro criaram-se espaços públicos de deliberação e negociação. Muitas comunidades passaram a ter acesso livre à água, por recorrerem ao preceito da dominialidade pública, forçando os antigos "donos" a compartilhar a água. Mas as conquistas são lentas e a lei não suprime as cercas e muros das propriedades privadas, sendo este um forte impeditivo para o acesso democrático às fontes de água.

Logo, os conflitos apresentam uma positividade por trazerem para a arena pública as múltiplas dimensionalidades e valores atribuídos à água, no sentido não simplesmente de postular regulações formais de direitos de 
uso, ou adaptações da gestão estatal, mas a abertura de espaços de diálogo. Espaços para a exposição dos variados argumentos, demandas e propostas de solução. A disputa pela água no Cariri permite perceber a relevância dos processos participativos para a construção de uma gestão pública que responda aos dilemas enfrentados e promova um acesso mais democrático e sustentável à água, seja ela abundante ou rara.

\section{BIBLIOGRAFÍA}

Acselrad, H. (org.) 2004: Conflitos Ambientais no Brasil. Rio de Janeiro (Brasil), Relume Dumará, Fundação Heinrich Boll.

Aquino, S. H. S. de 2019: Entre escassez, prioridades e negociações: a COGERH e os trajetos e destinos das águas que vêm do Sertão para a Metrópole. Tese do doutoramento, Universidade Federal do Ceará, Fortaleza (Brasil). http://www.repositorio.ufc br/handle/riufc/43292

Bouguerra, M. L. 2004: As batalhas da água. Por um bem comum da humanidade. Petrópolis (Brasil), Vozes

Brasil, 1997: Lei Nacional 9.433, de 8 de janeiro de 1997. Institui a Política Nacional de Recursos Hídricos. http://www. planalto. gov.br/ccivil_03/Leis/L9433.htm

Brasil, 2013: Plano Nacional de Saneamento Básico. Brasília (Brasil). http://www.mma.gov.br/cidades-sustentaveis/qualidade-do-ar/ item/485-plano-nacional-de-saneamento-b\%C3\%A1 sico

Brito, A. C. R. 2016: Águas para que(m): grandes obras hídricas e conflitos territoriais no Ceará. Curitiba (Brasil), PR, CRV.

Castro, J. E. 2016: Água e Democracia na América Latina. Campina Grande (Brasil), EDUEPB. Recuperado de: http://www.uepb.edu. br/download/ebooks/Agua-e-Democracia-na-America-Latina.pdf

Ceará, 1992: Lei Estadual 11.996, de 24 de julho de 1992. Dispõe sobre a Política Estadual de Recursos Hídricos. https://www. cogerh.com.br/legislacao-estadual/category/293-1992.html

COGERH, 2010: Cartilha Vamos Conhecer a Bacia do Salgado.

COGERH, 2014-2016: Relatórios de Atividades do Núcleo de Gestão da Bacia do Salgado.

CPT (Comissão Pastoral da Terra) 2019: Conflitos no campo Brasil 2018. Goiânia (Brasil), CPT Nacional. https://www.cptnacional. org.br/component/jdownloads/summary/41-conflitos-no-campo-brasil-publicacao/14154-conflitos-no-campo-brasil-2018

Diniz, J. N. B. 2014: Paisagens marginais: um estudo em perspectiva histórica de localidades portuárias no sertão brasileiro (18081851) e no deserto do Sudoeste africano (1884-1914). Dissertação de Mestrado, Universidade Federal de Santa Catarina, Florianópolis (Brasil). Recuperado de https://repositorio.ufsc.br/handle/123456789/123215. Consulta realizada em 18 de maio de 2019.

Galizoni, F. M. (coords.). 2013: Lavradores, águas e lavouras. Estudos sobre gestão camponesa de recursos hídricos no Alto Jequitinhonha. Belo Horizonte (Brasil), UFMG.
Hissa, I. A. 2005: Análise da realidade da Fonte Batateira no Cariri-Ce: Aspectos econômicos e legais do mercado de águas, Dissertação de mestrado, Universidade Federal do Ceará, Fortaleza (Brasil). http://www.repositorio.ufc.br/bitstream/riufc/16238/1/2005_dis_iahissa.pdf

ICMBIO-Instituto Chico Mendes de Conservação da Biodiversidade. 2011: Plano de Ação Nacional para a Conservação do soldadinhodo-araripe. Brasília (Brasil), ICMBIO. https://www.icmbio.gov.br/ portal/faunabrasileira/plano-de-acao-nacional-lista/614-planode-acao-nacional-para-conservacao-do-soldadinho-do-araripe

IPECE-Instituto de Pesquisa e Estratégia Econômica do Ceará. Ceará em Mapas, 2019. http://www2.ipece.ce.gov.br/atlas/

Jacobi, P. R. e Sinisgalli, P. de A. (orgs.) 2009: Dimensões Político Institucionais da Governança da Água na América Latina e Europa. São Paulo (Brasil), Annablume.

Kemper K. E., Gonçalves. J. Y. \& Bezerra, F. W. 1999: "Water allocation and trading in the Cariri Region-Ceará, Brazil", en Kemper, K. E. y Mariño, M. (eds). 1999: Institucional Frameworks in Successful Water Markets. Brazil, Spain and Colorado, USA. Word Bank Techical Paper, 427, 1-9.

Mauss, M. 2003: Sociologia e antropologia. Rio de Janeiro (Brasil), Cosac \& Naify.

Moraes Filho, E. (org.) 1983: Georg Simmel: Sociologia. São Paulo (Brasil), Ática.

Moulier-Boutang, Y. 1999: "L'art de la fugue" (Entrevista de Stany Grelet), Vacarme, 8. https://doi.org/10.3917/vaca.008.0003

Oliveira, J. F. A. 2017: Diagnóstico socioeconômico ambiental das áreas de influência direta da Chapada do Araripe, utilizando técnicas de geoprocessamento e sensoriamento remoto. Monografia de especialização, Universidade Regional do Cariri, Juazeiro do Norte (Brasil).

Orellana-Gavidia, S. 2013: "Compartiendo el agua: conflictos (micro) políticos en el acceso y distribución del agua. El caso de la Isla de Amantaní (Lago Titicaca, Perú)", Agua y Territorio, 2, 24-33. https://doi.org/10.17567/at.v7i2.1346

Ostrom, E. 2011: El Gobierno de los Bienes Comunes. La evolución de las instituciones de acción colectiva. Ciudad de México (MéxiCO), FCE-UNAM, IIS

Panez-Pinto, A. P., Faúndez-Vergara, R. y Mansilla-Quiñones, C. 2017: "Politización de la crisis hídrica en Chile: análisis del conflicto por el agua en la provincia de Petorca", Agua y Territorio, 10, 131-148. https://doi.org/10.17561/at.10.3614

Reis Júnior, D. de 0. 2014: Senhores e trabalhadores no Cariri cearense: terra, trabalho e conflitos na segunda metade do século XIX. Tese de doutoramento, Universidade Federal do Ceará, Fortaleza (Brasil). http://www.repositorio.ufc.br/handle/riufc/9543. Consulta realizada em 17 de maio de 2019.

Sabiá, R. J. 2000: Gerenciamento das fontes no Cariri. Uma perspectiva integrada e multidisciplinar. Dissertação de mestrado, Universidade Federal do Ceará, Fortaleza (Brasil). 
Sabiá, R. J. e Frischkorn, H. 2004: "Gestão das fontes da Chapada do Araripe: descaso ou incompetência". Anais do Congresso Brasileiro de Ciência e Tecnologia em Resíduos e Desenvolvimento Sustentável. Florianópolis (Brasil), ICTR, 1306-1313. http://docplayer.com.br/26388995-Ictr-2004-congresso-brasileiro-de-ciencia-e-tecnologia-em-residuos-e-desenvolvimento-sustentavel-costao-do-santinho-florianopolissanta-catarina.html

Sant'Anna, D. B. de. 2007: Cidade das águas: usos de rios, córregos, bicas e chafarizes em São Paulo (1822-1901). São Paulo (Brasil), Editora Senac São Paulo.

Santos, I. P. dos. 2014: A evolução do regime jurídico das águas doces no Brasil e no Ceará: análise do caso da fonte Batateira no Cariri-CE, Dissertação de Mestrado, Universidade de Fortaleza, Fortaleza (Brasil). http://bdtd.ibict.br/vufind/Record/UFOR_3df 603244f9facadf765db13ab9ae0a8

Silva, D. C., Aquino, S. H. S e Souza Filho, F. A. 2013: "Conflitos associados à gestão da água no semiárido brasileiro", Anais do XVI Congresso Brasileiro de Sociologia. Salvador (Brasil), SBS

Silva, F. O. E, Heikkila, T., Souza Filho, F. A. \& Silva, D. C. 2012: "Developing sustainable and replicable water supply systems in rural communities in Brazil", International Journal of Water Resources Development, 29 (4), 622-635. https://doi.org/10.1080/ 07900627.2012 .722027

Souza Filho., F. A. de. 2011: "A política nacional de recursos hídricos: desafios para sua implantação no semiárido brasileiro", en Medeiros, S. de S. et al. (orgs.): Recursos Hídricos em regiões áridas e semiáridas, Campina Grande (Brasil), INSA.

Souza, M. M. S. 2008: Aspectos jurídicos e ambientais das águas das fontes e os conflitos resultantes do uso para abastecimento humano: estudo de caso da Fonte Guaribas em Crato/CE. Monografia de Especialização, Universidade Federal do Ceará, Juazeiro do Norte (Brasil).

UNESCO, 2019: No dejar a nadie atrás. Informe Mundial de Naciones Unidas sobre el Desarrollo de los Recursos Hídricos 2019. París y Ciudad de México, UNESCO. https://unesdoc.unesco.org/ ark:/48223/pf0000367306?pos InSet=4\&queryld=ac9e70e58039-4577-94a3-158548a7f5a0. Consulta realizada em 18 de maio de 2019

Viana, V. B. e Costa, C. T. F. 2015: "Dimensões da Sustentabilidade Envolvidas Com a Questão da Água", Revista NAU Social, 6 (10), 23-33. https://doi.org/10.9771/ns.v6i10.31303 